\title{
Introduction: \\ The Peach Blossom Fan as Southern Drama
}

The centers of governmental power have clustered in the north, on the dusty Yellow River plains, through most of Chinese history as at the present time. To past residents of this region, "the south" did not mean the tropical southern coast where Canton lies, but the Yangtze Valley with its silk and tea and porcelain, its rich trade towns like Soochow and Yangchow, its landscapes lovingly recorded by the painters, and its preeminence in all the arts. Much of the action of The Peach Blossom Fan centers on Nanking, which holds a special place even among the glamorous cities of the south: for this reason it is especially appropriate that the play, as we shall show, should be in the "southern" style. Nanking in the fifth and sixth centuries of our era served as capital for native dynastic houses which, however decadent, ill-fated, and shortlived, at least kept alight the lamp of Chinese culture when the north was in the hands of overlords from beyond the frontiers. In the seventeenth century, when K'ung Shang-jen was writing his play, the mere mention of the Nanking pleasure-quarter on the banks of the Ch'in-huai River was still enough to bring wistful sighs from anyone who had dallied there only in his youth, or never at all. The Peach Blossom Fan draws constantly on the fading glories of yore to weave a backdrop of nostalgia for its tale of sad decline.

As terms in the history of Chinese drama, northern and southern define two generic types of play which at different times dominated the national stage. Readers of English have begun to know northern-style plays in translations such as S. I. Hsiung's Lady Precious Stream and Romance of the Western Chamber, but they have barely even heard of southern plays. By northern we mean, essentially, Yuan drama, which under the rule of the Yuan 
or Mongol dynasty (1280-1368) furnished the first Golden Age of the Chinese theatre. This Yuan or northern-style play (the Chinese term is $t s a-c h \ddot{u}$ ) is governed by the strictest conventions. It is quite short: four acts with the option of a "wedge," a short prefatory or interpolated segment. Each act of a northern play consists essentially of a song-set, a sequence of a dozen or so arias surrounded by dialogue. The arias are composed in a single musical mode and are allocated to a single character, obviously the lead character in the play. There is a freshness and naturalness about the poetry of these songs which perfectly matches the forceful action and the vigour of the dialogue: crude and creaky mechanisms somehow don't detract from the vital energy of the best of these plays. There is much self-introduction and soliloquy, much narration of offstage action, too much recapitulation of earlier scenes, but overall a remarkably tight organization of events into the four nucleic acts. The third act is usually climactic; the fourth will usually show the finest poetry, as the singer builds up images to explore the significance of what has been presented.

Although the southern style of drama has actually a longer history than the northern, dating back at least to the Sung dynasty, which preceded the Yuan, it did not come to dominance until the sixteenth and seventeenth centuries, during which time the Ming dynasty (1368-1644) yielded place to the Ch'ing or Manchu (1644-1911). Hundreds of southern-style plays (nan-hsi or ch'uan-ch'i) were written during these years. The Peach Blossom Fan, completed in 1699, was one of the last of the great ones.

The southern-style play contrasts strongly with its Yuan counterpart. In place of the tight four-act structure, with its concentration of dramatic situation around the songs of a single lead player, we are shown a sort of undulating cavalcade. There are many scenes: The Peach Blossom Fan, with forty plus, is not unduly long, for Peony Pavilion (Mu-tan t'ing) has fifty-five. The scenes vary in length and kind from short transitional, when narrative business is conducted without a great deal of singing, to lengthy "grand scenes" with many of the cast assembled for some crucial confrontation. Often there will be contrasting groupings of characters in a play (as for example, in The Peach Blossom Fan, the young hero Hou Fang-yü and his friends over against the Ma Shih-ying-Juan Ta-ch'eng clique). The "cavalcade" effect is created by the alternation of such groupings through successive scenes.

The traditional Chinese stage used no sets, and so there is complete freedom of movement and much scenic description 
(vicarious stage-setting) in dialogue and songs: Scene 8, "A Riverside Occasion," is a conspicuous example. The well-peopled "grand scene" will usually offer spectacular costuming and a feast of song with particularly fine arias for solo, duet, or choral rendering - for in the southern drama all characters may sing. This is the most striking departure from the Yuan convention of the single singing role. Certain other types of scene are also prescribed for the southern play: it must, by convention, contain at least a minimum number of love scenes, martial scenes, and comic scenes. As a matter of course, we find all these in The Peach Blossom Fan, for K'ung Shang-jen matched the story he had to tell quite precisely with the requirements of the genre.

The extraordinary length of the southern play (even further exaggerated by the use of very slow tempi for many of the songs) meant that one could hardly take in a complete performance at one sitting. The fifteen-day New Year's holiday, or the protracted birthday celebration of a high official or a member of the Imperial family, were favoured occasions for a performance which might spread over four or five evenings. The audience, knowing the play as every Chinese audience always seems to, would attend at its discretion: the connoisseurs for the great musical treats, the servants for the comic interludes, the children for the battle scenes. But because of the strenuous demands imposed by such a performance, the troupes themselves developed the practice of offering only selected scenes. They would construct a program for a single evening of scenes from three or four different plays, chosen to suit the particular resources of the company. These "selected scenes" were the ancestors of the Peking Opera plays of today.

Anyone who has seen Peking Opera, the classical theatre of China in its present incarnation, will be aware of the importance of role-types. The juvenile lead, the ingenue, and so on, are perhaps not so different from what we know in the West, but distinction of type is carried to a far higher degree. On an actor's role-type (or an actress' - only in certain historical periods were women barred from stage performance) depended the pitch of his voice, the pattern of his makeup, the manner of his gait and gesture, the way he sat down or held a fan.

Among the numerous dramatis personae of a play like The Peach Blossom Fan there would inevitably be several characters belonging to the same role-type. Thus the general Liu Liang-tso, the villainous grand secretary Ma Shih-ying, the singing-teacher Su K'un-sheng, and the minstrel Chang Yen-chu are all assigned to the 
ching or "painted-face" role: each would have special facial makeup, deep voice, tall stature (platform shoes), and exaggerated stride. The stage direction in the text of the play reads not just "enter Liu Liang-tso," but "enter the painted-face, costumed in armour as General Liu Liang-tso." By having a single ching actor play more than one of these parts, the size of the acting company could of course be held down below the level of a huge cast. The ch'ou or comic role-type in The Peach Blossom Fan plays the parts of the storyteller Liu Ching-t'ing, the bookseller Ts'ai Yi-so, a variety of servants and attendants, and an important female part, the singing-girl Cheng T'o-niang. We can imagine her as conspicuously ugly with her tart's makeup, lewd gestures, and regular caterwaul of a singing voice, since one of her major functions is to offset the demure elegance of the ingenue (tan) role, Fragrant Princess.

The poetic diction of the songs of the plays is a kind of loosened-up derivative of classical Chinese verse. Each song is composed to a specific, set metrical pattern. This is true of northern drama also, but the repertoire of available patterns is much larger for the southern style. It runs into hundreds, and one of the most jealously cherished aspects of the playwright's skill was his selection of the perfect metrical pattern for the effect he desired. Since each metrical pattern would imply a particular basic melody, he was also something of a composer, or at least arranger, of music. The accompaniment of the songs involved much use of gongs and drums for the martial sequences, but the most characteristic feature of southern drama was the use of the flute (as against the harsher stringed instruments of the northern style) to accompany much of the solo singing. The effect was of refinement almost to the point of languor, as the tremulous slow line of the flute, the modulations of high soprano or falsetto, and the delicate sway of sleeve and fan united to explore the last subtle suggestion of the lyrical text.

Buried among the hundreds of southern-style plays, hardly ever performed and seldom even read today, are scenes of great verbal beauty, lively passion, or effective comedy. There are only a handful of plays, though, which taken as a whole can match The Peach Blossom Fan for quality. Only one is available in a relatively complete (though prosaic and flat) English version: The Palace of Eternal Youth (Ch'ang-sheng tien) by Hung Shen (Peking: Foreign Languages Press, 1955). A musical comedy which enjoyed modest success on the Broadway stage in 1946, Lute Song by Will Irwin 
and Sidney Howard, was based on the early-Ming southern-style masterpiece of that title, but Irwin and Howard presumably relied on the French translation made by A. P. L. Bazin as early as 1841 , for there is still no complete English version of Lute Song ( $P^{\prime} i-p$ 'a chi). In another year or so, I hope to complete an English translation of Peony Pavilion (Mu-tan t'ing), which the master-dramatist T'ang Hsien-tsu was finishing just about the time Shakespeare wrote Romeo and Juliet.

In some ways, The Peach Blossom Fan is the most interesting of all these plays. It tells the story of the intrigues and treachery that led to the downfall of the Ming dynasty in 1644, fifty years before the play was written: the protagonists, as Sir Harold Acton makes clear in his preface, are all historical characters. The love affair (central to every southern play) is brilliantly integrated with the more weighty matter of the plot, for it is between a young scholar (Hou Fang-yü), who as a loyalist opposes corrupt officials selling out to the Manchu conquerors, and a courtesan of great strength of character, Fragrant Princess, who resists court bullies to follow her love. The martial scenes (also obligatory) perfectly reflect the unhappy progress of the Ming cause and depict in vivid terms the gallant but ultimately futile loyalty of generals like Huang Te-kung and Shih K'o-fa.

There can be no happy ending, given the historical authenticity of the action: the play ends with a Taoist ceremony of mourning for the fallen dynasty, and the resolve of the remaining loyalists to enter seclusion in the hills rather than serve an alien regime. The world of The Peach Blossom Fan is that late-Ming world of gross corruption, of callousness and cowardice and the breakdown of a long-cherished order. Yet the quality of life revealed in the play is of extraordinary cultivation and sensibility. There is a great poignancy in this contrast, and we are led to a deep respect for Hou Fang-yü, Liu Ching-t'ing, and Shih K'o-fa, as in their different ways they follow their doomed ideals.

The textual history of K'ung Shang-jen's play is fairly straightforward: it was printed within the author's lifetime, and subsequent editions have introduced few variations in the text. In revising the Chen-Acton translation, I have followed the excellent edition put out by the People's Literature Press in Peking in 1959, deriving much help from the copious annotations by Wang Chi-ssu and Su Huan-chung. The translation is complete except for a very few places - for example, in Scene 32 where the directions for the ceremonial of eulogy have been abridged to omit long strings of 
instructions of the "Kneel! Rise! Kneel!" kind from the Master of Ceremonies' speech. These commands, in performance, would punctuate an elaborate posturing dance, but they make for boring reading.

Chen and Acton have exploited the resources of English to reproduce with great success the high poetry of many songs, the contrasting low punning and bawdy badinage, the formal greetings and compliments between scholars, and the sometimes rather stiff and artificial soliloquies and speeches of self-introduction. No other genre in Chinese literature draws so widely on the resources of the language. One feature of these Ming-Ch'ing plays presents a perennial problem to the translator: this is the passion for allusion. In the present translation, many allusions have been footnoted; many more have been sacrificed to the interests of readability. In my own rendering of the final scenes, I followed Chen and Acton's lead by paraphrasing when the closest translation would have impossibly retarded the movement of the verse. To illustrate this, let me quote from Liu Ching-t'ing's ballad in the final scene. He is lamenting the fall of the Nanking court. Throughout his song, he moves back and forth between the recent disastrous collapse of the Ming regime and the comparable events of a thousand years earlier "when the house of Sui destroyed the Ch'en." So, when he comes to the despicable career of the traitor Juan Ta-ch'eng, he sings:

Past faults [admitted by Juan Ta-ch'eng in his own play] Spring Lantern [Riddles] he should recognize over again; But cliques and groupings he rejoins so that no seam shows; Borrowing a sword to kill his foe, [like the treacherous] Elder of Endless Joy [Feng Tao, a tenth-century Chief Minister],

Rubbing shoulders, flattering the eminent in the Halfway-toLeisure Hall [the villa by the West Lake built by the notorious traitor, the Southern Sung minister Chia Ssutao].

In line with the decisions made at similar knotty junctures by Chen and Acton, I decided to paraphrase rather than translate, to read:

Careless of past faults, Juan Ta-ch'eng

Fawned on the might of Ma Shih-ying,

Tricked and betrayed all who opposed him,

Slaughtered his foes with borrowed blade. 
This kind of rendering obviously obscures much of the erudition, and with this some of the depth and richness of the original. But it seems regrettably unavoidable if the play is to be enjoyed at all in English; and it is worth insisting that the true glory of The Peach Blossom Fan lies not in these precious displays of pedantry, but in those songs, the great majority, whose language and imagery are clear, direct, and deeply moving.

Cyril Birch 
